\title{
A Nexus between Green HRM (GHRM), Supply Chain Performance (SCP) and Business Performance (BP): The Mediating Role of Supply Chain Organizational Learning (SCOL)
}

\author{
Muafi iD, Rizqi Adhyka Kusumawati iD \\ Universitas Islam Indonesia (Indonesia) \\ muafi@uii.ac.id,rizqi.adbyka@uii.ac.id
}

Received: October 2020

Accepted: February 2021

\begin{abstract}
:
Purpose: This study tests and analyzes the relationship pattern (nexus) of Green HRM, SCP, and BP. In addition, this study also tests the mediation role of SCP in analyzing the relationship between GHRM and BP and the mediation role of SCP in analyzing the relationship between SCOL and BP.

Design/methodology: This study uses survey method. The survey is distributed to owners/managers of courier service SMEs in two provinces (Special Region of Yogyakarta and East Java) in Indonesia. The sampling technique is conducted purposively with 165 respondents. The data analysis technique uses AMOS 23.

Findings: SCOL has a positive effect on SCP and BP and mediates the effect of SCP on BP. The most interesting about the findings is GHRM has no effect on SCP and BP and SCP does not mediate GHRM on BP.

Research limitations/implications: Researcher use purposive sampling which has limitation of not being able to generalize the population in two provinces, namely Special Region of Yogyakarta and East Java. This is also not ideal approach to evaluate the impact of GHRM on SCP and BP and the impact of SCOL on SCP and BP. Courier service SMEs in this study have not implemented GHRM in ideal manner so they are unable to conclude the results in a comprehensive and transparent manner.
\end{abstract}

Managerial Implication: Companies need to consider aspects related to the courier service industry, namely digitalization of information and green innovation so their contribution can be seen in improving whole business performance. In addition, it is necessary to divide SMEs that have practiced GHRM and those that are not so they can make strategies and policies related to GHRM, SCP, BP and SCOL. It is also necessary to examine other aspects in improving the business sustainability of courier services, namely the complexity and service strategy orientation. SMEs who have more SCOL strategy will better implement GHRM practices associated with SCP and BP. This is important since competition in the courier service industry is getting tougher especially when faced with foreign competitors who already have global service standards.

Theory Implication: This study contributes the theory enrichment of SCOL aspect in mediating the relationship pattern between SCP and BP. This study also provides theoretical contributions namely GHRM has no effect on SCP and BP and SCP does not mediate GHRM on BP.

Originality/value: Study which examines the role of SCOL, especially when it is related to GHRM, SCP and BP is still limited in Asia. SME owners in the courier service industry rarely have good data integration in the system. The implementation of SC is starting from upstream to downstream processes so that SMEs need a well-planned and integrated SCOL in each work unit which ultimately have an impact on SCP and BP. 
Keywords: Green HRM (GHRM), Supply Chain Organizational Learning (Scol), Supply Chain Performance (Scp) and Business Performance (BP)

\section{To cite this article:}

Muafi \& Kusumawati, R.A. (2021). A nexus between Green HRM (GHRM), Supply Chain Performance (SCP) and Business Performance (BP): The mediating role of Supply Chain Organizational Learning (SCOL). Journal of Industrial Engineering and Management, 14(2), 329-344. https://doi.org/10.3926/jiem.3339

\section{Introduction}

Covid 19 pandemic era has caused companies increasingly concerned about risks and distuptions in their supply chain. At the start of COVID-19 outbreak, the focus of supply chain management was to meet customer needs quickly and responsively. However, in the "new normal" era, supply chain management experienced various obstacles in both manufacturing and service industries. The supply chain model for large, medium, and small companies inevitably has to undergo a complete transformation, considering that many companies panic because they are unable to cope with drastic changes in the market. In the current era, supply chain management is very complicated and experiences significant obstacles that require mitigation (Petersen \& Lemke, 2015). In a market that has competitive demands, supply chain flexibility has been recognized as a necessity in the context of operational requirements and service which always change (Willis, Genchev \& Chen, 2016). Whitten, Green and Zelbst (2012) describe that good supply chain management is supply chain management (MSC) which is characterized by "triple A supply chain", namely agile, adaptable, and aligned.

Study on the business performance achievement related to supply chain organizational learning (SCOL) is still limited in SMEs context (Willis et al., 2016; Muafi \& Uyun, 2018), especially in courier service SMEs. Even this sector has experienced very significant growth and requires the human resources contribution to develop logistics and supply chain capabilities (Ding, Kam \& Tsahuridu, 2010). In Indonesia, the network of courier and logistics service players is increasing and spreading throughout Indonesia. Courier service opportunities have grown rapidly. Association of Indonesian Express, Post and Logistics Service Companies (Asperindo) has target that the average growth level in the courier and logistics services industry must be 14 to $15 \%$. It seems that this industry has increasing performance from year to year. Not only old players are lucky, but new companies also feel the opportunity. Indonesia is the largest market in Southeast Asia due to Indonesia's large population so that it has a greater need for sending and receiving goods (Sindonews, 2020). This study focuses on the importance of examine SCOL that courier service SMEs must have in relation to GHRM and SC Performance and BP. This study fill the research gap because;

1. There is no study that integrates SCOL with GHRM, SCP, and BP. The implementation of the SC model in SMEs is still limited in Asia (Creelman, 2010; Li, Ragu-Nathan, Ragu-Nathan \& Subba-Rao, 2006), especially in the application of SCOL (Hult, Nichols \& Ketchen, 2003; Ojha, Acharya \& Cooper, 2018; Ojha, Struckell, Acharya \& Patel, 2018) so that it increase the knowledge contribution of SCOL, GHRM, SCP, and BP which are limited and still relevant.

2. The study on the GHRM implementation is still limited and needed for sustainable performance development (Al Romeedy, 2019; Yong, Yusliza, Ramayah \& Fawehinm, 2019), especially in the courier service industry which faced with intense competition.

3. SMEs who have a good supply chain (MSC) management system are rare, especially aspects related to SCM practices from upstream to downstream (Creelman, 2010; Muafi et al., 2020). This requires SMEs to become learning organizations that are agile, adaptable, and aligned. 
4. Global environmental demands require companies to increase SCOL effectively and efficiently (Creelman, 2010; Hult et al., 2003) because all companies have moved very fast and responsive in serving their customers, especially when supported by information technology that is growing rapidly.

5. Managers need to be able to plan and control risk management as a consequence of SC uncertainty and mitigation so that they can accurately identify risks, conduct assessments, and analyze the impact of risk events on performance measures of SC and BP as a whole (Gebremikael, 2018; Simba, Niemann, Kotze, \& Agigi, 2017; Petersen \& Lemke, 2015; Paul, 2014).

\section{Literature Review}

\subsection{Green HRM (GHRM), Supply Chain Performance (SCP), and Business Performance (BP)}

The current greening era requires human resource activities to be integrated with the environment (Yong et al., 2019). The HRM department has the additional responsibility of combining the environmentally based HRM philosophy with the company strategy and HRM policies. In the human resources field, the GHRM theme has emerged as a new research topic (Zaid et al. 2018; Bon et al. 2018; Nejati et al. 2017; Jabbour \& Jabbour, 2016; Cedeno et al. 2015; Khan et al. 2013 ; Menon, 2012).

GHRM involves several aspects of traditional HRM (recruitment, selection, performance evaluation, training, and rewards) associated with greening. Therefore, GHRM must be aligned with environmental objectives, strategic dimensions for HRM and organizational culture, teamwork, and employee empowerment (Jabbour \& Jabbour, 2016). Nejati et al. (2017) add that GHRM has several aspects including green recruitment and selection, green development and training, green employee empowerment, green pay / reward and green performance management and appraisal. The HRM aspect of environmental management is able to create and sustain pro-environmental organizations by recruiting employees who are willing to implement environmental management activities. Currently, human resource practitioners believe that environmental reputation is important (Sakka, 2018).

GHRM is a process of creating an environmentally based workforce that understand and appreciate environmentbased cultures in organizations (Sheikh et al, 2019). All of which require development, implementation, and improvement of a system with the aim that employees are oriented towards green environment-friendly (Mehta \& Chugan, 2015). When employees have an environment-based culture, it is hoped that employees will start to be friendly and familiar with the environment throughout the HRM process, from recruitment and selection to industrial relations practices. The limited study on GHRM makes it is needed to develop, especially those related to sustainable performance. GHRM is proven to have a significant effect on sustainable performance (Al Romeedy, 2019; Mousa \& Othman, 2019: Yong et al., 2019; Arulrajah, Opatha \& Nawaratne, 2015). Company managers have a significant role in increasing superior business performance (Alkerdawy, 2018). The application of environmentally based HRM results in increased productivity, cost efficiency, and employee retention (Sheikh et al, 2019; Mehta \& Chugan, 2015; Al Romeedy, 2019). Some literature proves that GHRM have a significant effect on business performance (Mwita, 2019; Al Romeedy, 2019; Sheikh et al., 2019; Fernando et al., 2019; Mousa \& Othman, 2019; Alkerdawy, 2018; Yusoff, Nejati, Kee \& Amran, 2018; Teimouri, Shokouhi, LaFevor, Khoury \& Jenab, 2014; Antonioli, Mancinelli \& Mazzanti, 2013). Teimouri et al.(2014) state that there is a significant relationship between HRM management and business strategy. This relationship shows an increase in HRM which is associated with environmental innovation so that it can improve company performance (Antonioli et al., 2013). Fernando, Jabbourc and Wahd (2019) add that the role of HRM has an effect on environmental innovation and ultimately has an impact on sustainable business performance.

\section{H. Green Human Resource Management (GHRM) has a significant effect on business performance (BP).}

GHRM involves environmental friendly HRM policies and practices. On the one hand, it helps organizations achieve their monetary goals through environmental imaging. On the other hand, it protects the environment from negative impacts that may be caused by organizational policies and actions (Mwita, 2020). GHRM has an important role in developing the company. To create GHRM, companies need to develop several aspects, namely electronic-based HRM management, environmental-based employee empowerment, and the role of HRM 
business partners (Yusliza, Othman \& Jabbour, 2017). The practice of GHRM can be used as an organizational resolution that uses the intersection point of each employee to inspire environmental performance activities and increase employee awareness of environmental issues and sustainable activities (Yusoff et al, 2018; Das \& Singh, 2016).

Several studies confirm that GHRM is able to affect SCP (Sakka, 2018; Jabbour \& Jabbour, 2016; Nejati et al. 2017; Zaid et al., 2018; Bon et al., 2018; Longoni et al. 2016; Cedeno et al. 2015; Khan et al. 2013; Menon, 2012; Hall et al., 2012). There are several aspects of HRM that are proven to have a significant effect on supply chain performance (Albahussain, et al., 2016; Menon, 2012) and BP (Zaid et al. 2018; Albahussain, et al., 2016). The results also confirm that SCP plays a role in mediating the relationship between HR practices and organizational performance. Therefore, in the future, it is very important for organizations to make efforts to implement exclusive human resource management practices such as Green HRM. Zaid et al. (2018) reinforce the findings that internal green SCM positively mediates the relationship between green HRM practices and sustainable performance.

\section{$H_{2}$. Green Human Resource Management (GHRM) has a significant effect on supply chain performance \\ $H_{3 .}$ Supply Chain Performance has a significant effect on Business performance \\ H. Supply Chain Performance mediates the effect of GHRM and Business performance}

\subsection{Supply Chain Organizational Learning (SCOL), Supply Chain Performance (SCP) and Business Performance (BP)}

Recently, literature which is related to organizational learning has developed rapidly (Ali, Peters, Khan, Ali \& Saif, 2020; Andreou et al. 2016; Bendig et al. 2018; Khunsoonthornkit \& Panjakajornsak, 2018; Ojha, Acharya et al., 2018; Ojha, Struckell et al., 2018; Chung, Yang \& Huang, 2015; Kalmuk \& Acar, 2015; Hu, 2014; Jiménez-Jiménez \& Sanz-Valle, 2011; Lopez, Peon \& Ordas, 2005), especially for SMEs (Muafi \& Uyun, 2018). Tennant \& Fernie, 2013; Hult et al., 2003; Hult, Nichols, Giunipero \& Hurley, 2000) reveal that supply chain organizations should use the best learning strategies routinely. It is conducted as a form of organizational reaction and intervention to situations and conditions found in the field. The reason is that the practice of SCOL in the world has not yet developed and encountered significant obstacles both theoretically and empirically, especially in Indonesia (Muafi \& Uyun, 2019). When a company is able to implement SCOL practices effectively and efficiently, it could improve organizational performance and competitive advantage (Muafi \& Uyun, 2019).

Pérez-Salazar, Aguilar-Lasserre, Cedillo-Campos and Hernández-González (2017) conducted knowledge management study in SC with a systematic review approach based on qualitative content analysis. The results find that knowledge management in SC have many functions, including; (1) supply chain integration, (2) improvement of intra and inter-relationships throughout supply chain, (3) alignment of supply chain strategies and (4) strengthening knowledge transfer in product development. This proves SCM requires human resources role who have ability to manage SC properly and demanded to conduct the SCOL process sustainable and continuously (Muafi, Siswanti, Diharto \& Salsabil, 2020). Muafi et al. (2020) state that SC human capital has a very significant role in product and process innovation. In the contingency approach, when an organization implements an innovation strategy, the company should implement an innovative SCOL. On the other hand, when implementing an imitation strategy, the company should implement an imitation SCOL so that organizational performance increases.

Supply chain is value chain that extends from supplier to end customer and definitely requires SCOL (Muafi \& Uyun, 2019). Azaadegan, Srinivasan, Blome and Tajeddini (2019) also provide solution related to supply chains where companies must improve organizational learning. Supply chain managers must work appropriately to integrate and coordinate their respective production, marketing, and financial functions with those of supply chain partners (Whitten et al, 2012). Roy, Silvestre and Singh (2020) view organizational learning as a temporal result that arises from the involvement of companies with production practices starting from upstream and downstream in the supply chain in a sustainable manner. This can be done by strengthening indirect pathways to 
organizational learning with suggesting companies to learn about supply chains in a sustainable manner by engaging in quality and environmental management systems.

Chung et al. (2015) analyze organizational learning in 2 aspects, namely explorative and exploitative learning. Both of these learning models can be used to improve SC performance and business performance. Organizational learning is a process by which companies develop new knowledge and insights from the general experiences of people in the organization and have potency to influence behavior and improve company capabilities (Jiménez-Jiménez \& Sanz-Valle, 2011). Organizational learning is the basis for gaining a sustainable competitive advantage and a key aspect for improving organizational performance (Jiménez-Jiménez \& Sanz-Valle, 2011). In addition, organizational learning provides an increase in company performance at the partnership level in diversification terms (Andreou, Louca \& Petrou, 2016). Ali et al. (2020) analyze organizational learning in hotels and find a significant relationship between OL on hotel performance. Likewise Willis et al. (2016) explain that supply chain integration (both internal and external) mediates the relationship between flexibility and SCOL performance. There is a positive relationship between cross-functional integration and integration between companies. This result is supported by Hult et al. (2000) which state that organizational learning has a positive effect on customer orientation and relationship commitment in the global supply chain. SCP is proven to be supported by SCOL (Roy et al. 2020; Azadegan et al. 2019; Sriyakul et al. 2019; Ojha, Acharya et al., 2018; Ojha, Struckell et al., 2018; Jian \& Li, 2016; Opengart, 2015; Whitten et al. 2012;) and also affect and correlate with business performance (Skipworth, Godsell, Wong, Saghiri \& Julien, 2015; Vivek \& Ravindran, 2009).

\section{$H_{5 .}$ SCOL has a significant positive effect on SCP. \\ $H_{6 .}$ SCOL has a significant positive effect on BP. \\ H7. SCP mediates the relationship between SCOL and BP.}

\section{Research Method}

Study was conducted by surveying the entire population of courier service SMEs in the Special Region of Yogyakarta and East Java. The growth of the courier service industry in Special Region of Yogyakarta and East Java increasing continuesly along with the existence of several related government regulations, for example the PSBB (large-scale social restrictions) in the Covid-19 pandemic era. It makes this service increasingly needed by the people of Special Region of Yogyakarta and East Java. The World Bank Logistics Performance Index data shows that Indonesia's logistics has increased very rapidly in the last three years. Currently, Indonesia is ranked 46th compared to 2016 which was ranked 63rd (Sindonews, 2020). Likewise, the potency for courier service business will increase with the penetration of the internet and wider infrastructure built by the government. Several courier service industries have changed business strategies to seize opportunities in the Covid 19 pandemic era, including in Special Region of Yogyakarta and East Java (Ekonomi Bisnis, 2020). The sampling technique in this study was conducted purposively with the following criterias: courier services SMEs which (1) have employees $<10$ people up to 300 people; (2) have annual income <USD one hundred thousand to 15 million USD; (3) assets ownership <\$ one hundred thousand to 15 million USD; and (4) have been operating for at least 5 years. The questionnaire was distributed to 200 respondents but those which analyzed were 165 courier service SMEs from Special Region of Yogyakarta and East Java. The scale technique in this study uses a Likert scale with a choice of 7 (very strongly agree) to 1 (strongly disagree) for the GHRM and SCOL variables. Meanwhile, the SCP and BP variables use Likert scale (1/very low to 7 /very high) where the respondent makes comparisons with similar competing companies during the last three years. This refers to Govindarajan (1988); Mohanty and Prakash (2014a; 2014b). The explanation of variables, operational definitions, indicators, measurement scales and reference sources can be seen in Table 1.

The hypothesis testing uses AMOS 23 analysis technique. After conducted testing, it is concluded that all variables and questionnaire items are valid and reliable. All AMOS 23 assumption tests are also fulfilled (Hair, Black, Babin \& Anderson., 2010) 


\begin{tabular}{|c|c|c|c|c|c|}
\hline No & $\begin{array}{l}\text { Variables and } \\
\text { references }\end{array}$ & Operational definition & Indicators/items & \multicolumn{2}{|c|}{ Measurement scale } \\
\hline 1. & $\begin{array}{l}\text { Green HRM (GHRM) } \\
\text { (Yong, et al., 2019; } \\
\text { Zaid, Jaaron \& Bon, } \\
\text { 2018; Bon, Zaid \& } \\
\text { Jaaron, 2018; Nejati, } \\
\text { Rabiei \& Jabbour } \\
\text { 2017; Jabbour \& } \\
\text { Jabbour, 2016) }\end{array}$ & $\begin{array}{l}\text { The process of creating } \\
\text { and developing an } \\
\text { environmentally based } \\
\text { workforce which includes } \\
\text { environmentally based HR } \\
\text { practices. }\end{array}$ & $\begin{array}{l}\text { Consists of } 5 \text { indicators / items } \\
\text { - green recruitment and } \\
\text { selection, } \\
\text { - green development and } \\
\text { training, } \\
\text { - green employee } \\
\text { empowerment, } \\
\text { - green pay / reward } \\
\text { - green performance } \\
\text { management }\end{array}$ & $\begin{array}{l}\text { Score } 1 \\
\text { Very } \\
\text { strongly } \\
\text { disagree }\end{array}$ & $\begin{array}{l}\text { Score } 7 \\
\text { Very } \\
\text { strongly } \\
\text { agree }\end{array}$ \\
\hline 2. & $\begin{array}{l}\text { SCOL } \\
\text { (Andreou et al., 2016; } \\
\text { Bendig, Enke, Thieme } \\
\text { \& Brettel, 2018; } \\
\text { Azadegan et al., 2019) }\end{array}$ & $\begin{array}{l}\text { The process of enhancing } \\
\text { action through knowledge } \\
\text { and understanding better } \\
\text { SC by refering to the } \\
\text { process for transforming } \\
\text { individually knowledge } \\
\text { acquired to be a part of } \\
\text { organizational knowledge } \\
\text { and helping companies } \\
\text { avoid repeating previous } \\
\text { mistakes. }\end{array}$ & $\begin{array}{l}\text { Consists of } 3 \text { indicators and } 6 \\
\text { items } \\
\text { - } \text { team orientation (collaboration } \\
\text { and teamwork) } \\
\text { - system orientation, } \\
\text { (understanding the } \\
\text { relationship between work } \\
\text { units, optimal service between } \\
\text { work units and external } \\
\text { customers) } \\
\text { - learning orientation (increasing } \\
\text { new skills, knowledge, and } \\
\text { abilities about SCM) } \\
\text { memory orientation (effective } \\
\text { and continuous } \\
\text { communication between } \\
\text { employees and work units and } \\
\text { sharing new knowledge } \\
\text { between employees) }\end{array}$ & $\begin{array}{l}\text { Score } 1 \\
\text { Very } \\
\text { strongly } \\
\text { disagree }\end{array}$ & $\begin{array}{l}\text { Score } 7 \\
\text { Very } \\
\text { strongly } \\
\text { agree }\end{array}$ \\
\hline 3. & $\begin{array}{l}\text { SCP } \\
\text { (Hausman, 2002; } \\
\text { Mufaiqih, Indarti, } \\
\text { Ciptono \& Kartikasari, } \\
\text { 2017) }\end{array}$ & $\begin{array}{l}\text { Supply chain performance } \\
\text { in meeting the needs of } \\
\text { the responsive final } \\
\text { customer. }\end{array}$ & $\begin{array}{l}\text { Consists of } 4 \text { items } \\
\text { - } \text { efficiency in using minimum } \\
\text { input } \\
\text { - } \text { availability of goods } \\
\text { - delivery on time } \\
\text { - } \text { supply chain supply capacity }\end{array}$ & $\begin{array}{l}\text { Score } 1 \\
\text { Very Low }\end{array}$ & $\begin{array}{l}\text { Score } 7 \\
\text { Very high }\end{array}$ \\
\hline 4. & $\begin{array}{l}\text { BP } \\
\text { (Prakash, Jha, Prasad } \\
\text { \& Singh, 2017; Mwita, } \\
\text { 2019; Skipworth, et al., } \\
\text { 2015) }\end{array}$ & $\begin{array}{l}\text { The result of company } \\
\text { business activities } \\
\text { conducted by all business } \\
\text { units and work units to } \\
\text { achieve goals during the } \\
\text { last three years }\end{array}$ & $\begin{array}{l}\text { Consists of two indicators: } \\
\text { financial performance ( } 3 \\
\text { items) and non-financial ( } 3 \\
\text { items) } \\
\text { - Financial: cost, capacity } \\
\text { utilization, inventory turnover. } \\
\text { - Non Financial: flexibility, } \\
\text { delivery speed, customer } \\
\text { satisfaction }\end{array}$ & $\begin{array}{l}\text { Score } 1 \\
\text { Very Low }\end{array}$ & $\begin{array}{l}\text { Score } 7 \\
\text { Very high }\end{array}$ \\
\hline
\end{tabular}

Table 1. variables, operational definitions, indicators / items, and measurement scale

\section{Results}

\subsection{Respondent's Description}

Based on data recapitulation result, the majority of the data shows; owner and manager of SMEs $(79 \%)$, have been in business for 5-10 years (87\%), serves local and regional customers (85\%); men (76\%); have annual income $<$ USD one hundred thousand to 15 million USD (100\%); asset ownership < \$ one hundred thousand to USD 15 million (100\%), and have permanent employee ownership of 2-5 people ( $87 \%)$. 


\subsection{Data Normality Testing}

The data is normal if the multivariate CR value is in the range $+/-2.58$. The results of the normality test in this study can be seen in Table 2 .

Table 2 shows that multivariate CR value is 1.795 , which is still in the $+/-2.58$ range, so the data in this study is normal.

Meanwhile, the outlier test conducted with Mahalanobis Distance measurement benchmarks. This study produces a chi-square value with a df of 21 indicators at a p level of $<0.001$ is 31.9. The result of the outlier test show that the highest Mahalanobis d-square value is 31.611 which is below 31.9 so that there is no outliers in this study.

\begin{tabular}{|l|r|r|r|r|r|r|}
\hline \multicolumn{1}{|c|}{ Variable } & min & max & skew & \multicolumn{1}{c|}{ c.r. } & \multicolumn{1}{c|}{ kurtosis } & \multicolumn{1}{c|}{ c.r. } \\
\hline SCP1 & 2.000 & 6.000 & -.291 & -1.528 & .220 & .576 \\
\hline FP3 & 2.000 & 6.000 & -.203 & -1.067 & .383 & 1.005 \\
\hline SCP4 & 2.000 & 7.000 & -.336 & -1.764 & .313 & .821 \\
\hline SCP3 & 2.000 & 6.000 & -.313 & -1.640 & .283 & .741 \\
\hline GHM5 & 2.000 & 7.000 & -.398 & -2.090 & .832 & 2.181 \\
\hline GHM4 & 2.000 & 6.000 & -.307 & -1.608 & .211 & .555 \\
\hline GHM3 & 2.000 & 7.000 & -.101 & -.531 & .612 & 1.605 \\
\hline LO1 & 2.000 & 6.000 & -.420 & -2.203 & .298 & .781 \\
\hline LO2 & 2.000 & 7.000 & -.163 & -.854 & .576 & 1.510 \\
\hline SO1 & 2.000 & 7.000 & -.467 & -2.447 & .749 & 1.963 \\
\hline SO2 & 2.000 & 6.000 & -.521 & -2.730 & .467 & 1.225 \\
\hline FP2 & 2.000 & 7.000 & -.176 & -.924 & .338 & .887 \\
\hline FP1 & 2.000 & 7.000 & .041 & .214 & .648 & 1.699 \\
\hline TO1 & 2.000 & 7.000 & -.595 & -3.122 & 1.146 & 3.005 \\
\hline TO2 & 2.000 & 6.000 & -.536 & -2.810 & .601 & 1.575 \\
\hline NFP2 & 2.000 & 7.000 & -.313 & -1.640 & .886 & 2.322 \\
\hline NFP1 & 2.000 & 6.000 & -.423 & -2.217 & .278 & .730 \\
\hline SCP2 & 7.000 & -.327 & -1.716 & .952 & 2.496 \\
\hline GHM1 & 6.000 & -.225 & -1.181 & -.039 & -.103 \\
\hline GHM2 & 7.000 & -.172 & -.903 & .206 & .541 \\
\hline Multivariate & & & & & 8.290 & 1.795 \\
\hline
\end{tabular}

Table 2. Normality Test Result

\subsection{Confirmatory Analysis}

Confirmatory analysis is used by looking at the loading factor value with a minimum number $\geq 0.5$ or ideally $\geq 0.7$. From the results, there was 1 indicator which have value below 0.5 , namely NFP3, so it must be dropped from the study. The result of the final value loading factor is shown in Table 3.

In table 3 , there are no indicators which have loading factor value below 0.5 so all indicators are valid. Furthermore, analysis of the goodness of fit / GoF model is conducted. Based on the results of the GoF test, it is found that all the criteria had been met the requirement except RMSEA and GFI (marginal Fit). This condition is still acceptable (Hair et al., 2010) so that this study model is considered fit. The GoF test results are shown in Table 4. 


\begin{tabular}{|c|c|c|r|}
\hline \multicolumn{2}{|c|}{} & & Loading Factors \\
\hline GHM2 & $<---$ & GHRM & 0.805 \\
\hline GHM1 & $<---$ & GHRM & 0.813 \\
\hline GHM3 & $<---$ & GHRM & 0.801 \\
\hline GHM4 & $<---$ & GHRM & 0.796 \\
\hline GHM5 & $<---$ & GHRM & 0.685 \\
\hline SCP1 & $<---$ & SCP & 0.772 \\
\hline SCP2 & $<---$ & SCP & 1.413 \\
\hline SCP3 & $<---$ & SCP & 0.842 \\
\hline SCP4 & $<---$ & SCP & 0.886 \\
\hline TO2 & $<---$ & T & 0.823 \\
\hline TO1 & $<---$ & T & 0.746 \\
\hline SO2 & $<---$ & SO & 0.829 \\
\hline SO1 & $<---$ & SO & 0.832 \\
\hline LO2 & $<---$ & LO & 0.829 \\
\hline LO1 & $<---$ & LO & 0.691 \\
\hline FP1 & $<---$ & FP & 0.792 \\
\hline FP2 & $<---$ & FP & 0.808 \\
\hline FP3 & $<---$ & FP & 0.593 \\
\hline NFP1 & $<---$ & NFP & 0.670 \\
\hline NFP2 & $<---$ & NFP & \\
\hline
\end{tabular}

Table 3. Loading Factors

\begin{tabular}{|c|c|c|c|c|}
\hline \multicolumn{1}{|c|}{ Fit Index } & Goodness of Fit & Criteria & Cut-off value & Description \\
\hline \multirow{2}{*}{ Absolute Fit } & RMSEA & $\leq 0.08$ & 0.089 & Marginal Fit \\
\cline { 2 - 5 } & GFI & $\geq 0.90$ & 0.861 & Marginal Fit \\
\hline \multirow{2}{*}{ Incremental Fit } & TLI & $\geq 0.90$ & 0.911 & Fit \\
\cline { 2 - 5 } & CFI & $\geq 0.90$ & 0.927 & Fit \\
\hline \multirow{2}{*}{ Parsimony Fit } & PGFI & $\geq 0.60$ & 0.635 & Fit \\
\cline { 2 - 5 } & PNFI & $\geq 0.60$ & 0.718 & Fit \\
\hline
\end{tabular}

Table 4. Goodness of Fit Test Result

\subsection{Reliability Test}

Good construct reliability is when the construct reliability value is $>0.7$ and the extracted variance value is $>0.5$. The results of the reliability test can be seen in Table 5 .

Based on Table 5, it can be seen that the data used for this study is reliable.

\begin{tabular}{|c|c|c|c|c|}
\hline Variables & Indicators & Loading Standard & $\mathbf{C R}$ & $\mathbf{V E}$ \\
\hline \multirow{5}{*}{$\begin{array}{l}\text { Green Human } \\
\text { Resource } \\
\text { Management }\end{array}$} & GHM2 & 0.805 & \multirow{5}{*}{0.9} & \multirow{5}{*}{0.6} \\
\hline & GHM1 & 0.813 & & \\
\hline & GHM3 & 0.801 & & \\
\hline & GHM4 & 0.796 & & \\
\hline & GHM5 & 0.685 & & \\
\hline \multirow{4}{*}{$\begin{array}{l}\text { Supply Chain } \\
\text { Performance }\end{array}$} & SCP1 & 0.772 & \multirow{4}{*}{1.0} & \multirow{4}{*}{1.0} \\
\hline & SCP2 & 1.413 & & \\
\hline & SCP3 & 0.842 & & \\
\hline & SCP4 & 0.886 & & \\
\hline \multirow{6}{*}{$\begin{array}{l}\text { Supply Chain } \\
\text { Organizational } \\
\text { Learning }\end{array}$} & TO2 & 0.823 & \multirow{6}{*}{0.9} & \multirow{6}{*}{0.7} \\
\hline & TO1 & 0.746 & & \\
\hline & $\mathrm{SO} 2$ & 0.829 & & \\
\hline & SO1 & 0.832 & & \\
\hline & LO2 & 0.856 & & \\
\hline & LO1 & 0.829 & & \\
\hline
\end{tabular}




\begin{tabular}{|c|c|c|c|c|}
\hline Variables & Indicators & Loading Standard & CR & VE \\
\hline \multirow{5}{*}{$\begin{array}{l}\text { Business } \\
\text { Performance }\end{array}$} & FP1 & 0.691 & \multirow{5}{*}{0.8} & \multirow{5}{*}{0.5} \\
\hline & FP2 & 0.792 & & \\
\hline & FP3 & 0.808 & & \\
\hline & NFP1 & 0.593 & & \\
\hline & NFP2 & 0.67 & & \\
\hline
\end{tabular}

Table 5. Reliability Test Result

\subsubsection{Hypothesis Test}

The results of regression weight test in this study can be seen in Figure 1, Tables 6 and 7.

\begin{tabular}{|c|c|c|c|r|r|r|r|c|}
\hline Hypotheses & \multicolumn{2}{|c|}{$\begin{array}{c}\text { Relationship } \\
\text { between variables }\end{array}$} & & Estimate & \multicolumn{1}{c|}{ S.E. } & \multicolumn{1}{c|}{ C.R. } & \multicolumn{1}{c|}{ P } & Label \\
\hline H1 (rejected) & BP & $<---$ & GHRM & .053 & .085 & .620 & .536 & ns \\
\hline H2 (rejected) & SCP & $<---$ & GHRM & .083 & .166 & .497 & .619 & ns \\
\hline H3 (rejected) & BP & $<--$ & SCP & .166 & .027 & 6.073 & $* * *$ & sign \\
\hline H5 (accepted) & SCP & $<---$ & SCOL & .900 & .156 & 5.782 & $* * *$ & sign \\
\hline H6 (accepted) & BP & $<---$ & SCOL & .450 & .091 & 4.959 & $* * *$ & Sign \\
\hline
\end{tabular}

Note: sign $=$ significant; $\mathrm{ns}=$ non significant

Table 6. Hypothesis Testing

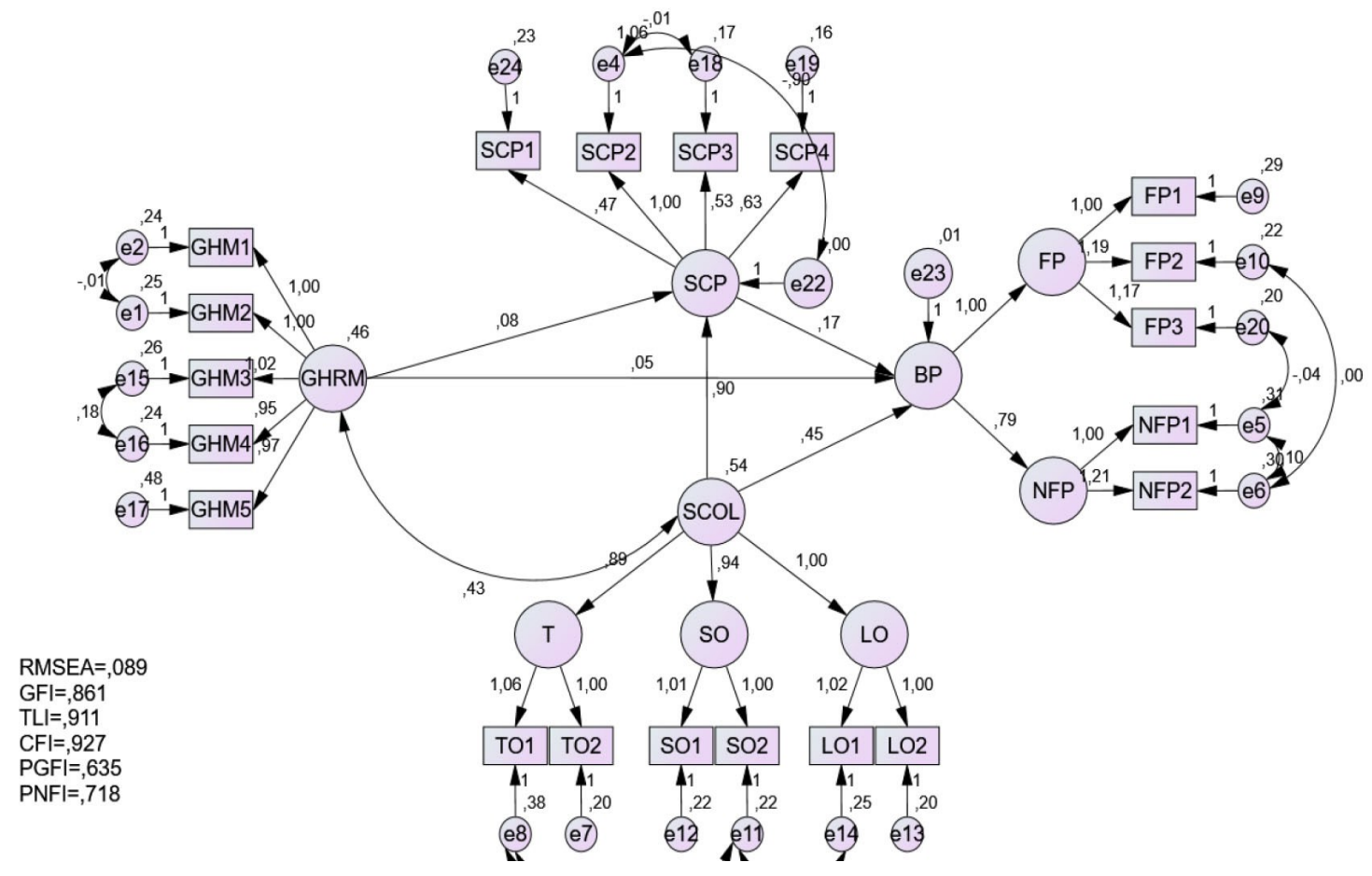

Figure 1. Full Model Path Diagram

\subsubsection{Mediation Testing}

Mediation testing can be seen from the significance of the indirect effect between variables. The results of the indirect effect analysis can be seen in Table 7 . 


\begin{tabular}{|c|c|c|c|c|c|c|c|c|c|}
\hline & SCOL & GHRM & SCP & BP & LO & SO & FP & T & NFP \\
\hline SCP & $\ldots$ & $\ldots$ & $\ldots$ & $\ldots$ & $\ldots$ & $\ldots$ & $\ldots$ & $\ldots$ & $\ldots$ \\
\hline BP & .008 & .633 & $\ldots$ & $\ldots$ & $\ldots$ & $\ldots$ & $\ldots$ & $\ldots$ & $\ldots$ \\
\hline
\end{tabular}

Table 7. Mediation Test Result

Table 7 explains that;

1. The effect of GHRM on BP mediated by SCP has a significance value of 0.633. This result proves that SCP is not able to significantly mediate the effect of GHRM on BP (H4 is rejected).

2. The effect of SCOL on BP mediated by SCP has a significance value of 0.008 so that SCP is able to significantly mediate the effect of SCOL on BP (H7 is supported).

\section{Discussion and Implications}

GHRM is a set of HR practices that are compiled from several environmental-based aspects. Several HR practices such as recruitment, selection, performance management, and awards must be environmentally oriented (Mwita, 2019; Al Romeedy, 2019; Yong et al., 2019; Arulrajah et al., 2015). The study results prove that GHRM has no positive effect on increasing SCP and BP. This means it rejects $\mathbf{H 1}$ and $\mathbf{H 2}$. This finding is not relevant with Sakka (2018); (Jabbour \& Jabbour, 2016; Nejati et al. 2017; Zaid et al., 2018; Bon et al., 2018; Longoni, Luzzini \& Guerci, 2016; Cedeño, Farrero, Guitart-Tarrés \& Vallejo, 2015; Khan, Taha, Ghouri, Khan \& Yong 2013; Menon, 2012; Hall, Hall \& Rigsbee, 2012) which state that in increasing the SCP, companies should be able to practice GHRM effectively and efficiently. In addition, these findings are also not in line with previous studies that found GHRM is able to increase BP (Al Romeedy, 2019; Mousa \& Othman, 2019; Yong et al., 2019; Arulrajah, et al., 2015). When companies implement GHRM in all work units, the company could increase productivity, cost efficiency, and retain employees (Sheikh., Islam \& Rahman, 2019; Mehta \& Chugan, 2015; Al Romeedy, 2019). Likewise, these findings also do not corroborate previous studies that SCP is able to mediate GHRM against BP (Zaid et al. 2018; Albahussain, Elgaraihy \& Mobarak, 2016). This means it rejects H3. In SCP, companies should emphasize the efficiency of minimum inputs use, ensure the availability of goods to customers, make deliveries on time, and provide the supply chain capacity for goods / services.

When the study was conducted, most of the courier service SMEs did not fully understand and fully implement GHRM practices. This condition is difficult for them to implement it because during the practice they experience various obstacles. The obstacle that often occurs besides cost and time is they often ignore environmental elements in each of their HR processes / practices. They are not well prepared because they do not have sufficient skills and competencies in GHRM practices, especially when it includes training and employee development activities. They tend to have a tentative conclusion that when GHRM is implemented, it does not have much benefit and impact on SCP and BP. This condition should not occur because when companies implement GHRM effectively and efficiently it would have an impact on input efficiency, ensure the goods availability, goods delivery on time and supply chain capacity availability, all of which can be oriented to environmental aspects.

There are few industries that are oriented towards environmental friendly technology, because business people are more likely to focus on profits rather than saving the environment. Courier service SMEs need to pay attention to the GHRM aspects from the start and make environmental friendly technology innovations that save SC costs in line with the company's goal of increasing business sustainability towards a competitive green courier service industry. GHRM is very important as one of the SME courier service efforts to protect and preserve the environment because it must be realized that without an environment, the company will not be able to explore the products and services offered. Ecological requirements still considered as the main criteria in any SCM process while ensuring the sustainability of a competitive and profitable economy.

There are several important indicators for Courier service SMEs in Special Province of Yogyakarta and East Java that should be noted and continuously improved, namely financial and non-financial performance. Financial aspects include; cost, capacity utilization, and inventory turnover. Meanwhile, non-financial aspects include: flexibility, 
delivery speed, customer satisfaction. The level of competition for courier services is getting higher because the market is very wide and varied. Today's customers are very smart to choose services that provide excellent satisfaction, fast, and accurate responses while still paying attention to environmental aspects. In fact, they really count the length of service time, price, and security. The interesting thing to offer is when the goods are received by the customers there is a message of environmental preservation in every service provided. This can be a different and unique promotional weapon to influence customers to remember and reuse their services.

The results prove that SCOL has a significant positive effect on SCP (H5 is supported) and BP (H6 is supported). Likewise, SCP mediates the relationship between SCOL and BP (H7 is supported). This supports previous studies from Roy et al. (2020); (Azadegan et al., 2019; Sriyakul, Prianto \& Jermsittiparsert, 2019; Ojha, Acharya et al., 2018; Ojha, Struckell et al., 2018; Jian \& Li, 2016; Opengart, 2015; Whitten et al., 2012; Skipworth, et al., 2015; Vivek \& Ravindran, 2009). Currently, SCOL in courier service SMEs must really be paid attention and improved. Along with the intense level of competition and the use of information technology that is growing rapidly. This makes companies have to make systematic changes to increase new knowledge (Andreou et al., 2016). Organizational learning is the process of enhancing action through knowledge and better understanding by referring to the process of transforming individually acquired knowledge into organizational knowledge and helping companies avoid repeating previous mistakes (Bendig et al., 2018), especially in SCOL. Bendig et al. (2018); Ojha, Acharya et al. (2018) and Ojha, Struckell et al., (2018) recommend that SMEs should constantly develop employee competencies (skills, knowledge, attitude) to increase SCP and BP besides their competitive advantage position. Leaders and employees of courier service SMEs need to collaborate and cooperate well, understand the relationship between work units, provide optimal service between work units and external customers. Besides, it is necessary to increase new skills, knowledge, and abilities about SCM. JNE is an example of a courier service company that has survived and successful. JNE always puts forward cooperation or collaboration to overcome various challenges today, so it can complement each other. For example, in overcoming prohibition of crossing motorbikes on certain roads in DKI Jakarta, JNE organizes bicycle couriers, in collaboration with Westbike Messenger Service (WMS) (Swa.co.id, 2020).

Courier service SMEs are also supposed to conduct effective and sustainable communication and share new knowledge among employees. All of which are very important to improve the long-term prosperity of the organization and business performance (Jajja, Catha \& Farooq, 2018; Dubey, Luo, Gunasekaran, Akter, Hazen \& Douglas et al., 2018). SCOL is able to mediate the relationship between SCP and BP. This is evidently proven by the interviews results with several courier service SMEs owners who are also being managers. When companies are careless to learn something new, such as information system applications to support the speed of the SCM system, the company will be increasingly abandoned by its customers. The number of new knowledge related to the SCM system makes courier service SMEs have to race against time.

Currently, many new courier companies are being responded to positively by the market because they are able to provide services that are relevant to the present or provide different expectations from the existing courier business model. Besides that, there is a pattern of changing customer behavior, including customers who come from the millienal generation where they usually demand instant, easy, and served very quickly. This strengthens the evidence that consumer expectations have changed, which has given birth to new patterns and standards in terms of delivery of goods, namely pick-up of goods on the spot, free, and the goods arrive to consumers in hours (Swa.co.id, 2020). This situation and condition made the old company difficult to serve it and lose with the courier service start-up company. This condition happens because they do not have competent human resources who are willing to conduct continuous learning process, especially in SCOL so that they have the ability to adapt quickly.

\section{Limitation and Suggestions for Future Study}

This study is only focused on two provinces in Indonesia, namely Special Region of Yogyakarta and East Java so it may limit the generalizability of the findings. The collection method is also done purposively with cross-work unit data. It is not an ideal approach to evaluate the impact of SCOL on SCP and BP. Courier service SMEs in this study also have not implemented GHRM in an ideal manner so that they are not able to generalize courier service SMEs object as a whole. This study has used a static approach because the data collection is done by cross section. 
In the future, it is better to expand the study area, use longitudinal data, and choose courier service SMEs that have correctly implemented GHRM in SCOL context to validate the model and study results.

\section{Declaration of Conflicting Interests}

The authors declared no potential conflicts of interest with respect to the research, authorship, and/or publication of this article.

\section{Funding}

We express our gratitude to DPPM Universitas Islam Indonesia who has funded this research with the scheme of Riset Unggulan of 2020/2021 (003/Dir/DPPM/70/Pen.Unggulan/12/2020

\section{References}

Alkerdawy, M. (2018). The Role of Corporate Support for Employee Volunteering in Strengthening the Impact of Green Human Resource ManagementPractices on Corporate Social Responsibility inthe Egyptian Firms. European Management Review, 10(2), 1-12.

Al Romeedy, B.S. (2019). Green human resource management in Egyptian travel agencies: constraints of implementation and requirements for success. Journal of Human Resources in Hospitality \& Tourism, 18(4), 529-548. https://doi.org/10.1080/15332845.2019.1626969

Albahussain, S.A., Elgaraihy, W.H., \& Mobarak, A.K.M. (2016). Measuring the Impact of Human Resource Management Practices on Organizational Performance with the Mediating Role of Supply Chain Performance between Them in Saudi Industrial Large Organizations. Arcbives of Business Research, 4(2), 20-36. https://doi.org/10.14738/abr.42.1915

Ali, S., Peters, L., Khan, I.U., Ali, W., \& Saif, N. (2020). Organizational Learning and Hotel Performance: The Role of Capabilities' Hierarchy. International Journal of Hospitality Management, 85.

https://doi.org/10.1016/j.ijhm.2019.102349

Andreou, P., Louca, C., \& Petrou, A. (2016). Organizational learning and corporate diversification performance. Journal of Business Research, 69(9), 3270-3284. https://doi.org/10.1016/j.jbusres.2016.02.022

Antonioli, D., Mancinelli, S., \& Mazzanti, M. (2013). Is environmental innovation embedded within highperformance organisational changes? The role of human resource management and complementarity in green business strategies. Research Policy, 42(4), 975-988. https://doi.org/10.1016/j.respol.2012.12.005

Arulrajah, A.A., Opatha, H.H.D.N.P., \& Nawaratne, N.N.J. (2015). Green Human Resource Management Practices: A Review. Sri Lankan Journal of Human Resource Management, 5(1), 1-16. https://doi.org/10.4038/sljhrm.v5i1.5624

Azadegan, A., Srinivasan, R., Blome, C., \& Tajeddini, K. (2019). Learning from near-miss events: An organizational learning perspective on supply chain disruption response. International Journal of Production Economics, 216(18), 215-226. https://doi.org/10.1016/j.ijpe.2019.04.021

Bendig, D., Enke, S., Thieme, N., \& Brettel, M. (2018). Performance implications of cross-functional coopetition in new product development: the mediating role of organizational learning. Industrial Marketing Management, 73(14), 137-153. https://doi.org/10.1016/j.indmarman.2018.02.007

Bon, A.T.A., Zaid, A., \& Jaaron, A. (2018). Green human resource management, Green supply chain management practices. IEOM Society International, 167-176.

Cedeño, M.G., Farrero, J.M., Guitart-Tarrés, L., \& Vallejo, J.M. (2015). Impact of Human Resources on Supply Chain Management and Performance. Industrial Management \& Data Systems, 115(1), 2-35.

https://doi.org/10.1108/IMDS-09-2014-0246

Chung, H.F.L., Yang, Z., \& Huang, P.H. (2015). How does organizational learning matter in strategic business performance? The contingency role of guanxi networking. Journal of Business Research, 68(6), 1216-1224. https://doi.org/10.1016/j.jbusres.2014.11.016 
Creelman, D. (2010). Big Idea: Tim Giehll on Human Capital Supply Chains. Creelman Research, 3(1), 1-3. Available at: https://creelmanresearchlibrary.files.wordpress.com/2010/10/creelman-2010-vol-3-01-giehll-on-hc-scm.pdf

Das, S.C., \& Singh, R.K. (2016). Green HRM and Organizational Sustainability: An Empirical Review. Kegees Journal of Social Science, 8(1-2), 227-236.

Ding, M.J., Kam, B.H., \& Tsahuridu, E.E. (2010). Does Human Resource Management Contribute to the Development of Logistics and Supply Chain Capabilities? An Empirical Study of Logistics Service Providers in China. Research and Practice in Human Resource Management, 18(2), 15-34.

Dubey, R., Luo, Z., Gunasekaran, A., Akter, S., Hazen, B.T., \& Douglas, M.A. (2018). Big data and predictive analytics in humanitarian supply chains. International Journal of Logistics Management, 29(2), 485-512.

Ekonomi.Bisnis (2020). Siasat Bisnis Kurir Paket Meraup Untung. Available at: https://ekonomi.bisnis.com/read/20200420/98/1229875/siasat-bisnis-kurir-paket-meraup-untung (Accesed: September 2020).

Fernando, Y., Jabbourc, C.J., \& Wahd, W.-X. (2019). Pursuing green growth in technology firms through the connections between environmental innovation and sustainable business performance: Does service capability matter. Resources, Conservation \& Recycling, 141(7), 8-20. https://doi.org/10.1016/j.resconrec.2018.09.031

Gebremikael, F. (2018). An investigation of the impact of social media platforms on supply chain performance through competitive intelligence using AHP model. Dissertation. North Dakota State University.

Govindarajan, V. (1988). A contingency approach to strategy implementation at the business unit level: Integrating administrative mechanism with strategy. Academic of Management Journal, 31, 828-853.

https://doi.org/10.2307/256341

Hall, L.M., Hall, L.C., \& Rigsbee, C. (2012). Strategic human resource management and supply chain orientation. Human Resource Management Review, 23(4), 366-377. https:/ /doi.org/10.1016/j.hrmr.2012.07.002

Hausman, W.H. (2002). Supply Chain Performance Metrics. Stanford University.

Hair, J.F.Jr., Black, W.C., Babin, B.J., \& Anderson, R.E., (2010). Multivariate Data Analysis (7th ed.). Essex, UK: Person Prentice Hall.

Hu, B. (2014). Linking business models with technological innovation performance through organizational learning. European Management Journal, 32(4), 587-595. https://doi.org/10.1016/j.emj.2013.10.009

Hult, G.T.M., Nichols, E.L., Giunipero, L.C., \& Hurley, R.F. (2000). Global Organizational Learning in the Supply Chain: A Low Versus High Learning Study. Journal of International Marketing, 8(3), 61-83.

https://doi.org/10.1509/jimk.8.3.61.19628

Hult, G.T.M., Nichols, E.L., \& Ketchen, D.J. (2003). Organizational Learning as a Strategic Resource in Supply Management. Journal of Operations Management, 21(5), 541-556. https://doi.org/10.1016/j.jom.2003.02.001

Jabbour, E., \& Jabbour, A.L. (2016). Green Human Resource Management and Green Supply Chain. Journal of Cleaner Production, 112(3), 1824-1833. https://doi.org/10.1016/j.jclepro.2015.01.052

Jajja, M.S.S., Catha, K.A., \& Farooq, S. (2018). Impact of Supply Chain Risk on Agility Performance: Mediating Role of Supply Chain Integration. International journal of production economics, 205, 118-138. https://doi.org/10.1016/j.ijpe.2018.08.032

Jian, Z.M., \& Li, L. (2016). The Impact of Organizational Learning and Supply. International Conference on Logistics, Informatics and Service Sciences (LISS) (119, 1-5).

Jiménez-Jiménez, D., \& Sanz-Valle, R. (2011). Innovation, organizational learning, and performance. Journal of Business Research, 64(4), 408-417. https://doi.org/10.1016/j.jbusres.2010.09.010

Kalmuk, G., \& Acar, A. (2015). The Mediating Role of Organizational Learning Capability on the Relationship Between Innovation and Firm's Performance: A Conceptual Framework. Procedia - Social and Behavioral Sciences, 210(20), 164-169. https://doi.org/10.1016/j.sbspro.2015.11.355 
Khan, N., Taha, S., Ghouri, A., Khan, M., \& Yong, K.C. (2013). The Impact Of HRM Practices On Supply Chain Manageme nt Success in SME. Scientific Journal of Logistics, 9(3), 177-189. https://doi.org/10.2139/ssrn.2281372

Khunsoonthornkit, A., \& Panjakajornsak, V. (2018). Structural equation model to assess the impact of learning organization and commitment on the performance of research organizations. Kasetsart Journal of Social Sciences, 39(3), 457-462. https://doi.org/10.1016/j.kjss.2018.07.003

Li, S., Ragu-Nathan, B., Ragu-Nathan, T.S., \& Subba-Rao, S. (2006). The Impact of Supply Chain Management Practices on Competitive Advantage and Organizational Performance. Omega, 34(2), 107-124.

https://doi.org/10.1016/j.omega.2004.08.002

Longoni, A., Luzzini, D., \& Guerci, M. (2016). Deploying Environmental Management Across Functions: The Relationship Between Green Human Resource Management and Green Supply Chain Management. Journal of Business Ethics, 151, 1081-1095. https://doi.org/10.1007/s10551-016-3228-1

Lopez, S.P., Peon, J.M., \& Ordas, C.V. (2005). Human Resource Practices Organizational Learning and Business Performance. Human Resource Development International, 8(2), 147-164. https://doi.org/10.1080/13678860500100103

Mehta, K., \& Chugan, K.P. (2015). Green HRM in Pursuit of Environmentally Sustainable Business. Universal Journal of Industrial and Business Management, 3(3), 74-81. https:// doi.org/10.13189/ujibm.2015.030302

Menon, S. (2012). Human resource practices, supply chain performance and well being. International Journal of Manpower, 33(7), 769-785. https://doi.org/10.1108/01437721211268311

Mohanty, R.P., \& Prakash, A. (2014a). Green supply chain management practices in India: a confirmatory empirical study. Production \& Manufacturing Research, 2(1), 438-456. https:/ / doi.org/10.1080/21693277.2014.921127

Mohanty, R.P., \& Prakash, A. (2014b). Green supply chain management practices in India: an empirical study. Production Planning \& Control, 25(16), 1322-1337. https://doi.org/10.1080/09537287.2013.832822

Mousa, S., \& Othman, M. (2019). The impact of green human resource management practices on sustainable. Journal Pre-proof, 243(29), 3-45. https://doi.org/10.1016/j.jclepro.2019.118595

Muafi., \& Uyun, Q. (2018). The Influence of Islamic HRM Practices on Organizational Learning and Its Impact on Environmental, Social and Religious Performance. Journal of Entrepreneurship Education, 21(Special Issue), 1-9.

Muafi., \& Uyun, Q. (2019). Imitation vs Innovation: Is there an alignment between supply chain organizational learning and Islamic HRM practices? Holistica, 10(3), 143-156. https://doi.org/10.2478/hjbpa-2019-0034

Muafi., Siswanti, Y., Diharto, A.K., \& Salsabil, I. (2020). Innovation Culture and Process in Mediating Human Capital Supply Chain on Firm Performance, Journal of Asian Finance, Economics and Business, 7(9), $593-602$. https://doi.org/10.13106/jafeb.2020.vol7.no9.593

Mufaqih, I.A., Indarti, N., Ciptono, W.S., \& Kartikasari. (2017). Pengaruh Integrasi, bergbagi informasi dan penundaan pada kinerja rantai pasokan. Studi pada Usaha Kecil Menengah Batik di Indonesia. Jurnal Siasat Bisnis, 21(1), 19-36. https://doi.org/10.20885/jsb.vol21.iss1.art2

Mwita, K.M. (2019). Conceptual Review of Green Human Resource Managament Practices. East African Journal of Social and Applied Sciences (EAJ-SAS), 1(2), 13-20.

Nejati, M., Rabiei, S., \& Jabbour, E. (2017). Envisioning the invisible: Understanding the synergy between green human resource management and green supply chain management in manufacturing firms in Iran in light of the moderating effect of employees' resistance to change. Journal of Cleaner Production, 168(17), 163-172. https://doi.org/10.1016/j.jclepro.2017.08.213

Ojha, D., Acharya, C., \& Cooper, D. (2018). Transformational leadership and supply chain ambidexterity: Mediating role of supply chain organizational learning and moderating role of uncertainty. International Journal of Production Economics, 197(18), 215-231. https://doi.org/10.1016/j.ijpe.2018.01.001

Ojha, D., Struckell, E., Acharya, C., \& Patel, P. (2018). Supply chain organizational learning, exploration, exploitation, and firm performance: A creation-dispersion perspective. International Journal of Production Economics, 204(7), 70-82. https://doi.org/10.1016/j.ijpe.2018.07.025 
Opengart, R. (2015). Supply chain management and Learning Organization: a merging of literatures. International Journal of Commerce and Management, 25(2), 183-195. https:/ / doi.org/10.1108/IJCoMA-10-2012-0063

Paul, J. (2014). Panduan Penerapan Transformasi Rantai Suplai dengan Model SCOR ${ }^{\circledR}$. Jakarta: Penerbit PPM.

Pérez-Salazar, M.R., Aguilar-Lasserre, A.A., Cedillo-Campos, M.G., \& Hernández-González, J.C.H. (2017). The Role of Knowledge Management in Supply Chain Management: A Literature Review, Journal of Industrial Engineering and Management, 10(4):711-788. https://doi.org/10.3926/jiem.2144

Petersen, H.L., \& Lemke, F. (2015). Mitigating reputational risks in supply chains. Supply Chain Management: An International Journal, 20(5), 495-510. https://doi.org/10.1108/SCM-09-2014-0320

Prakash, A., Jha, S.K., Prasad, K.D., \& Singh, A.K. (2017). Productivity, quality and business performance: an empirical study. International Journal of Productivity and Performance Management, 66(1), 78-91. https://doi.org/10.1108/IJPPM-03-2015-0041

Roy, V., Silvestre, B., \& Singh , S. (2020). Reactive and proactive pathways to sustainable apparel supply chains: Manufacturer's perspective on stakeholder salience and organizational learning toward responsible management. International Journal of Production Economics, 277(12), 1-13. https://doi.org/10.1016/j.ijpe.2020.107672

Sakka, S.E. (2018). Impact of green human resource management (GHRM) practices. Global Journal of Human Resource Management, 6(3), 70-78.

Sheikh, W., Islam, M.S., \& Rahman, F. (2019). Implementing Green Human Resource Managament. International Journal of Human Resource, 9(3), 117-130. https://doi.org/10.24247/ijhrmrjun201915

Simba, S., Niemann, W., Kotze, T., \& Agigi, A. (2017). Supply chain risk management processes for resilience: A study of South African grocery manufacturing. Journal of Transport and Supply Chain Management, 11, 1-13. https://doi.org/10.4102/jtscm.v11i0.325

Sindonews (2020). https://ekbis.sindonews.com/berita/1472008/34/2020-potensi-pertumbuhan-bisnis-logistik-lebih-dari-30 (Accessed: September 2020).

Skipworth, H., Godsell, J., Wong, C.Y., Saghiri, S., \& Julien, D. (2015). Supply chain alignment for improved business performance: an empirical study. Supply Chain Management: An International Journal, 20(5), 511-533. https://doi.org/10.1108/SCM-06-2014-0188

Sriyakul, T., Prianto, A.L., \& Jermsittiparsert, K. (2019). Is the supply chain orientation in an agile supply chain determining the supply chain performance?. Humanities \& Social Sciences Reviews, 7(3), 695-702. https://doi.org/10.18510/hssr.2019.73100

Swa.co.id. (2020). https://swa.co.id/swa/trends/marketing/geliat-jne-di-tengah-pusaran-persaingan (Accessed: September 2020).

Teimouri, H., Shokouhi, E.B., LaFevor, K., Khoury, S., \& Jenab, K. (2014). Concurrent Alignment of Human Resource Management and Business. Strategic Management Quarterly, 2(3), 71-80. https://doi.org/10.15640/smq.v2n3$4 \mathrm{a} 4$

Tennant, S., \& Fernie,S. (2013). Organizational learning in construction supply chains. Engineering, Construction and Architectural Management, 20(1), 83-98. https://doi.org/10.1108/09699981311288691

Vivek, N., \& Ravindran, S. (2009). An Empirical Study on the Impact of Supplier Performance on Organizational Performance: A Supply Chain Perspective. South Asian Journal of Management, 61(3), 61-70.

Whitten, G., Green Jr, K., \& Zelbst, P. (2012). Triple-A supply chain. International Journal of Operations \& Production Management, 32(1), 28-48. https://doi.org/10.1108/01443571211195727

Willis, P.G., Genchev, S.E., \& Chen, H. (2016). Supply chain learning, integration, and flexibility performance: An empirical study in India. The International Journal of Logistics Management, 27(3), 755-769.

https://doi.org/10.1108/IJLM-03-2014-0042 
Yong, J.Y., Yusliza, M.Y., Ramayah, T., \& Fawehinmi, O. (2019). Nexus between Green Intellectual Capital and Green Human Resource Management. Journal of Cleaner Production, 215, 364-374.

https://doi.org/10.1016/j.jclepro.2018.12.306

Yusliza, M.-Y., Othman, N.Z., \& Jabbour, C.C. (2017). Deciphering the implementation of green human resource management in an emerging economy. Journal of Management Development, 36(10), 1230-1246.

https://doi.org/10.1108/JMD-01-2017-0027

Yusoff, Y.M., Nejati, M., Kee, D.M., \& Amran, A. (2018). Linking Green Human Resource Management Practices to Environmental Performance in Hotel Industry. Global Business Review, 21(3), 1-18.

https://doi.org/10.1177/0972150918779294

Zaid, A., Jaaron, A., \& Bon, A. T. (2018). The impact of green human resource management and green supply. Journal of Cleaner Production, 204(84), 965-979. https://doi.org/10.1016/j.jclepro.2018.09.062

Journal of Industrial Engineering and Management, 2021 (www.jiem.org)

\section{(ब) $\Theta \Theta$}

Article's contents are provided on an Attribution-Non Commercial 4.0 Creative commons International License. Readers are allowed to copy, distribute and communicate article's contents, provided the author's and Journal of Industrial Engineering and Management's names are included. It must not be used for commercial purposes. To see the complete license contents, please visit https://creativecommons.org/licenses/by-nc/4.0/. 